\title{
PENGARUH AERASI BERTINGKAT DENGAN KOMBINASI SARINGAN PASIR, KARBON AKTIF, DAN ZEOLIT DALAM MENYISIHKAN PARAMETER Fe DAN Mn DARI AIR TANAH DI PESANTREN AR-RAUDHATUL HASANAH
}

\author{
Abdul Hafidz Nainggolan ${ }^{1}$, Ahmad Perwira Mulia Tarigan², Hafizhul Khair ${ }^{3}$ \\ ${ }^{1,3}$ Program Studi Teknik Lingkungan, Fakultas Teknik, Univesitas Sumatera Utara \\ Jalan Alumni Kampus USU, Medan 20155 \\ ${ }^{2}$ Departemen Teknik Sipil, Fakultas Teknik, Universitas Sumatera Utara \\ Jalan Perpustakaan Kampus USU, Medan 20155 \\ E-mail: abdul.hafidz.n@gmail.com
}

\begin{abstract}
ABSTRAK
Air tanah yang jika dibiarkan membentuk endapan kuning menunjukkan bahwa masih mengandung kadar Fe dan Mn yang tinggi, sehingga diperlukan suatu metode yang baik dalam kualitas dan ekonomis untuk meningkatkan kualitas air tanah. Penelitian yang bersifat eksperimen ini bertujuan untuk mengetahui pengaruh aerasi bertingkat dengan kombinasi saringan pasir, karbon aktif dan zeolit. Pemeriksaan sampel dilakukan secara continuous sampling setiap 1 jam sekali dalam 5 jam pada alat 1 (aerasi 2 tingkat dilanjutkan dengan saringan pasir, karbon aktif, dan zeolit), alat 2 (aerasi 2 tingkat dengan kombinasi zeolit dilanjutkan dengan saringan pasir, karbon aktif, dan zeolit), dan alat 3 (saringan pasir, karbon aktif, dan zeolit). Penurunan kadar Fe yang tertinggi ialah menggunakan alat 1 dengan efisiensi penurunan sebesar 47,22 \%. Sedangkan penurunan kadar Mn yang terdapat pada setiap alat dengan efisiensi penurunan sebesar $100 \%$. Hasil uji statistik menunjukkan bahwa ada perbedaan konsentrasi $\mathrm{Fe}$ pada alat 1 , alat 2 dan alat $3 p(0.028<0.05)$. Tidak ada perbedaan konsentrasi Mn pada alat 1, alat 2 dan alat 3 p (0.146 > 0.05).
\end{abstract}

Kata Kunci: Aerasi Bertingkat, Air Tanah, Fe, Mn, Saringan Pasir Karbon Aktif Zeolit

\begin{abstract}
Groundwater if allowed to form a yellow precipitate indicates that contains high levels of Fe and Mn are high, so we need a method that is good in quality and economical way to improve the quality of groundwater. Experimental research that aims to determine the effect of aeration is terraced with a combination of sand, activated carbon and zeolite filter. Examination of the samples is done continuous sampling every 1 hour within 5 hours of the treatment 1 (aeration 2 levels followed by a sand, activated carbon, and zeolite filter), the treatment 2 (aeration 2 levels with a combination of zeolite followed by a sand, activated carbon, and zeolite filter), and the treatment 3 (sand, activated carbon, and zeolite filter). The best decreased levels of Fe is to use the treatment 1 with an efficiency decrease of 47,22\%. Whereas decreased levels of Mn best is on each treatment with the efficiency of a decrease of $100 \%$. Statistical analysis showed that there are differences in the levels of Fe in the tool 1 , tool 2 and the tool $3 p(0.028<0.05)$. There is no difference in the levels of Mn on treatment 1 , treatment 2 , and treatment $3 p(0146>0.05)$.
\end{abstract}

Keywords:Groundwater, Fe, Mn, Multilevel aeration, Sand activated carbon zeolite filter 


\section{PENDAHULUAN}

Air merupakan kebutuhan vital makhluk hidup. Proses kehidupan tidak dapat berjalan tanpa adanya air yang memadai. Kebutuhan utama untuk terselenggaranya kesehatan yang baik ialah tersedianya air dari aspek kuantitas, kualitas, dan kontinuitas (Asmadi dkk, 2011). Pesantren Ar-Raudhatul Hasanah menggunakan air tanah sebagai sumber air baku untuk segala kebutuhan air. Namun, salah satu sumber air tersebut berasa, keruh, menimbulkan bercak kuning pada pakaian dan mengendap pada dinding pipa.

Karakteristik tersebut menunjukkan air mengandung besi $(\mathrm{Fe})$ dan mangan $(\mathrm{Mn})$ yang tinggi. Dalam konsentrasi besar besi dapat merusak dinding usus hingga kematian. Sedangkan mangan dalam jumlah besar dalam air minum bersifat neurotoksik dengan gejala insomnia, kemudian lemah pada kaki dan otot muka sehingga ekspresi muka menjadi beku (Soemirat, 2014).

Penelitian ini bertujuan untuk menelaah pengaruh aerasi bertingkat dengan kombinasi media pasir, karbon aktif, dan zeolit terhadap penurunan konsentrasi $\mathrm{Fe}$ dan $\mathrm{Mn}$ dengan parameter pendukung $\mathrm{pH}$, suhu, dan debit yang dapat diproduksi dengan kombinasi media tersebut. Pada penelitian Handarbeni (2013) tentang keefektifan susunan media filter zeolit-arang aktif-pasir silika dalam menurunkan kadar besi $(\mathrm{Fe})$ air sumur dimana kadar Fe turun dari 2,90 mg/l menjadi 0,18 $\mathrm{mg} / \mathrm{l}$ dengan keefektifan sebesar 93,56\%.

\section{METODOLOGI}

Penelitian dilakukan dua kali percobaan, dengan tiap percobaan selama 5 jam. Lokasi penelitian dilakukan di Pondok Pesantren Ar Raudlatul Hasanah, Kota Medan. Parameter yang diuji yaitu $\mathrm{Fe}, \mathrm{Mn}, \mathrm{pH}$, suhu dan oksigen terlarut. Sampel Fe dan Mn diperiksa di Balai Laboratorium Kesehatan Lingkungan (BLKL) Medan dan percobaan kedua di Balai Teknik Kesehatan Lingkungan dan Pengendalian Penyakit (BTKL) Medan. Parameter $\mathrm{pH}$, suhu, dan oksigen terlarut diperiksa langsung di lokasi penelitian. Lokasi penelitian dapat dilihat pada Gambar 1.

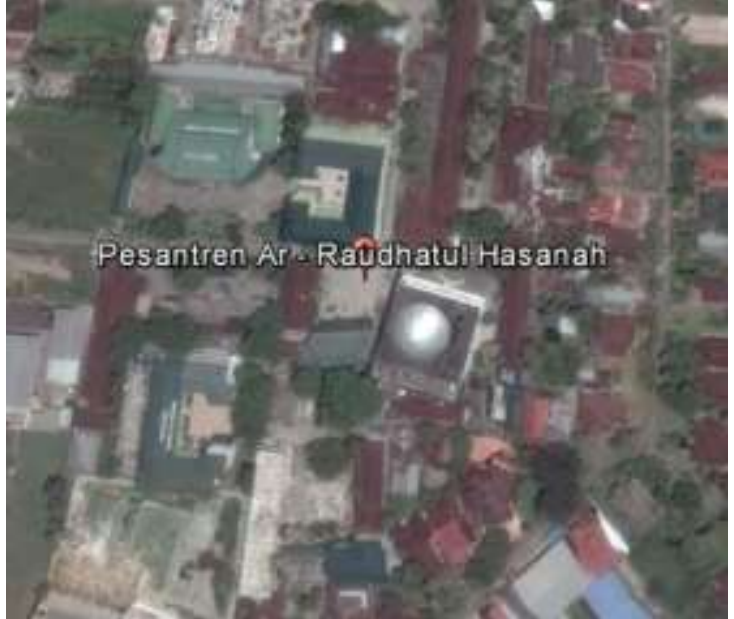

Gambar 1 Lokasi Pesantren Ar Raudhatul Hasanah

Sumber air yang digunakan ialah tangki air sumur bor I. Sampel input diambil sekali dari air kran yang pertama mengalir. Pengambilan sampel output dilakukan secara continuous sampling setiap 1 jam sekali dalam 5 jam pada alat 1 (aerasi 2 tingkat dilanjutkan dengan saringan pasir, karbon aktif, dan zeolit), alat 2 (aerasi 2 tingkat dengan kombinasi zeolit dilanjutkan dengan saringan pasir, karbon aktif, dan zeolit), dan alat 3 (saringan pasir, karbon aktif, dan zeolit). Diameter masingmasing media yang digunakan yaitu kerikil (5$9 \mathrm{~mm})$, pasir (0,5-1 mm), karbon Aktif (0,5$2,5 \mathrm{~mm})$, dan zeolit $(\leq 10 \mathrm{~mm})$. Debit air yang digunakan ialah $240 \mathrm{ml} / \mathrm{menit}$. Wadah aerasi berdiameter $10 \mathrm{~cm}$ dengan tinggi $20 \mathrm{~cm}$, dilubangi pada bagian tengah sebanyak 30 lubang berdiameter $2 \mathrm{~mm}$. Pada alat 2 wadah aerasi diisi dengan zeolit dengan ketebalan 3 $\mathrm{cm}$, sedangkan pada wadah aerasi alat 1 tidak ada menggunakan zeolit. Wadah media berdiameter $10 \mathrm{~cm}$ dengan tinggi $70 \mathrm{~cm}$. Kran input dan output menggunakan kran 3/4". Pada Gambar 1 dapat dilihat desain dari tiap-tiap alat. 


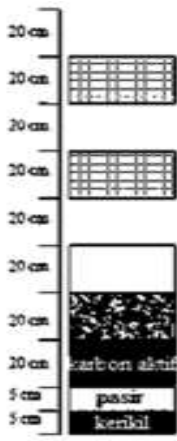

Alat 1

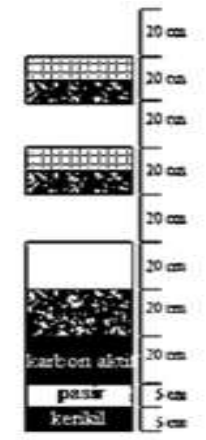

Alat 2

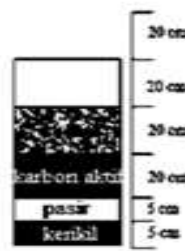

Alat 3

Gambar 2 Desain Alat Dengan Variasi Kombinasi Aerasi Bertingkat

\section{HASIL DAN PEMBAHASAN}

\section{Hasil Uji pH}

Hasil pengukuran $\mathrm{pH}$ sebelum pengolahan pada percobaan pertama ialah 7,57 dan 7,47

Tabel 1 pH sesudah pengolahan pada Alat 1, Alat 2 dan Alat 3

\begin{tabular}{|c|c|c|c|c|c|}
\hline \multicolumn{6}{|c|}{ Percobaan Pertama } \\
\hline \multirow{2}{*}{ Alat } & 1 & 2 & 3 & 4 & 5 \\
\cline { 2 - 6 } & 8,93 & 8,81 & 8,64 & 8,46 & 8,41 \\
\hline 1 & 8,64 & 8,77 & 8,47 & 8,31 & 8,42 \\
\hline 2 & 8,74 & 8,66 & 8,30 & 8,31 & 8,38 \\
\hline 3 & 1 & 2 & 3 & 4 & 5 \\
\hline \multicolumn{7}{|c|}{ Percobaan Kedua } \\
\hline \multirow{2}{*}{ Alat } & 8,26 & 8,38 & 8,33 & 8,28 & 8,26 \\
\cline { 2 - 6 } & 8,28 & 8,35 & 8,27 & 8,30 & 8,21 \\
\hline 1 & 8,18 & 8,05 & 8,05 & 8,10 & 8,10 \\
\hline 2 &
\end{tabular}

Proses aerasi menyebabkan kenaikan $\mathrm{pH}$ pada air hasil aerasi. Grafik hasil uji $\mathrm{pH}$ dapat dilihat pada Gambar 2. Proses aerasi akan menyebabkan mangan teroksidasi oleh oksigen. Mangan akan terikat dengan $\mathrm{SO}_{4}$ yang bersifat asam sehingga jika $\mathrm{SO}_{4}{ }_{4}$ dihilangkan dengan menguapnya $\mathrm{CaSO}_{4}$ yang merupakan gas bersifat asam, maka $\mathrm{pH}$ larutan akan naik. Persamaan reaksi oksidasi mangan yaitu (Rahmawati, 2009):

$$
\begin{array}{r}
2 \mathrm{MnSO}_{4}+2 \mathrm{Ca}\left(\mathrm{HCO}_{3}\right)+\mathrm{O}_{2} \rightarrow \\
2 \mathrm{MnO}_{2}+2 \mathrm{CaSO}_{4}+2 \mathrm{H}_{2} \mathrm{O}+4 \mathrm{CO}_{2}
\end{array}
$$

Pada Gambar 2 dilihat bahwa $\mathrm{pH}$ mengalami kenaikan yang tinggi pada 1 jam pertama kemudian mengalami penurunan secara bertahap pada jam-jam berikutnya. Peningkatan $\mathrm{pH}$ yang tinggi dikarenakan media yang digunakan terutama zeolit dan karbon aktif belum tercuci maksimal. Hal itu pada percobaan kedua. Nilai $\mathrm{pH}$ sesudah pengolahan pada alat 1 , alat 2 dan alat 3 dapat dilihat pada Tabel 1. Derajat keasaman air minum harus netral, tidak boleh bersifat asam maupun basa (Kusnaedi, 2010). Hasil pemeriksaan $\mathrm{pH}$ pada alat 1 , alat 2 dan alat 3 selain pada dua jam awal pengujian pada percobaan pertama jika dibandingkan dengan Peraturan Menteri Kesehatan RI No.492/MENKES/PER/IV/2010 tentang persyaratan air minum, dimana standar $\mathrm{pH}$ yang diperbolehkan berkisar antara 6,5 - 8,5, maka pH sampel air sebelum dan setelah penyaringan masih berada dalam standar baku mutu yang diperbolehkan. ditunjukkan oleh penurunan nilai $\mathrm{pH}$ secara bertahap setelah alat dijalankan.

Zeolit berfungsi menaikkan $\mathrm{pH}$ dan mengurangi kandungan besi (Fe) (Linsley, 1985). Sejalan dengan penelitian Rahayu yang menguji pengaruh penambahan massa zeolit dengan peningkatan $\mathrm{pH}$ dimana didapatkan hasil bahwa penambahan massa zeolit berpengaruh terhadap peningkatan $\mathrm{pH}$ dari 5,08 menjadi 6,64 dengan massa zeolit $600 \mathrm{~g}$.

Peningkatan nilai $\mathrm{pH}$ air juga dapat disebabkan adanya kation dalam karbon aktif yang terlarut dalam air (Jamilatum dan Setyawan). Pada penelitian Fatriani (2009) tentang pengaruh konsentrasi dan lama perendaman arang aktif tempurung kelapa menunjukkan bahwa konsentrasi dan lama perendaman berpengaruh nyata terhadap kenaikan $\mathrm{pH}$. Nilai $\mathrm{pH}$ awal pada penelitian 
tersebut ialah 6,48 setelah arang aktif tempurung kelapa dimasukan terjadi kenaikan dan setiap konsentrasi mempunyai batas maksimum kenaikan $\mathrm{pH}$ air menurut waktu perendaman, pada konsentrasi 0,3 gram dapat meningkatkan $\mathrm{pH}$ air dari 6,48 menjadi ratarata 6,64, pada konsentrasi arang aktif 0,6 gram kenaikan $\mathrm{pH}$ menjadi rata-rata 6,71, konsentrasi arang aktif 0,9 gram peningkatan $\mathrm{pH}$ menjadi rata-rata 6,74 .

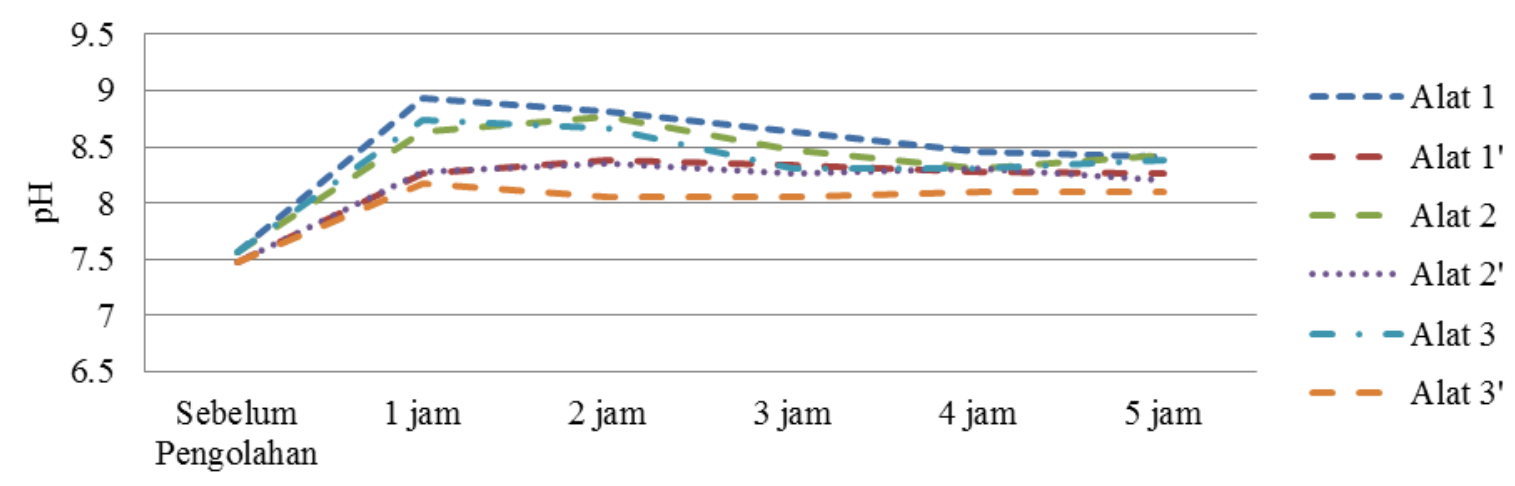

Gambar 2 Hasil uji pH (alat 1, 2, dan 3 ialah percobaan pertama sedangkan alat 1', 2' dan 3' ialah percobaan kedua)

\section{Hasil Uji Suhu}

Hasil pengukuran suhu sebelum penyaringan air pada tiap alat ialah $27,4{ }^{\circ} \mathrm{C}$ (percobaan pertama) dan $27,1^{\circ} \mathrm{C}$ (percobaan kedua). Pada Tabel 2 dapat diketahui suhu air sesudah pengolahan pada Alat 1, Alat 2 dan Alat 3. Air yang baik harus memiliki temperatur sama dengan temperatur udara $\left(20-26^{\circ} \mathrm{C}\right)$ (Kusnaedi, 2010). Berdasarkan hasil pemeriksaan suhu air baik sebelum mendapatkan perlakuan maupun setelah mendapatkan perlakuan dengan alat penyaring air selama 5 jam. Dari hasil pengukuran suhu tersebut diketahui bahwasanya alat penyaring air tidak memberikan pengaruh yang nyata terhadap suhu. Jika dibandingkan dengan Peraturan

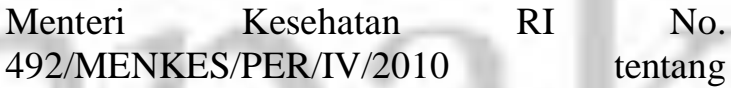
persyaratan air minum, dimana suhu yang diperbolehkan adalah $28 \pm 3{ }^{\circ} \mathrm{C}\left(25{ }^{\circ} \mathrm{C}-31\right.$ ${ }^{\circ} \mathrm{C}$ ), maka suhu air yang diperiksa tersebut masih diperbolehkan.

Tabel 2 Suhu air sesudah pengolahan pada Alat 1, Alat 2 dan Alat 3

\begin{tabular}{|c|c|c|c|c|c|}
\hline \multicolumn{7}{|c|}{ Percobaan Pertama } \\
\hline \multirow{2}{*}{ Alat } & \multicolumn{5}{|c|}{ Pengukuran Suhu $\left({ }^{\circ} \mathrm{C}\right)$ pada jam ke- } \\
\cline { 2 - 6 } & 1 & 2 & 3 & 4 & 5 \\
\hline 1 & 27,6 & 27,5 & 27,7 & 27,7 & 26,8 \\
\hline 2 & 27,3 & 27,9 & 27,8 & 27,9 & 27,7 \\
\hline 3 & 27,5 & 28,0 & 28,0 & 28,1 & 5 \\
\hline \multicolumn{7}{|c|}{ Percobaan Kedua } \\
\hline \multirow{2}{*}{ Alat } & 1 & 2 & 3 & 4 & 28,8 \\
\hline & 26,6 & 27,3 & 28,1 & 28,2 & 28,8 \\
\hline 2 & 26,9 & 27,6 & 28,6 & 28,2 & 29,0 \\
\hline
\end{tabular}

Suhu dapat mempengaruhi sejumlah parameter lain mutu air. Laju reaksi kimia dan biokimia meningkat dengan meningkatnya suhu. Kelarutan gas menurun dan kelarutan mineral meningkat dengan meningkatnya suhu (Suprihatin dan Suparno, 2013). Fluktuasi suhu air setelah penyaringan dapat dilihat pada Gambar 3.

Dari Gambar 3 tersebut dapat dilihat pada percobaan pertama suhu stabil pada jam ke 2 sampai jam ke 4 dan mengalami penurunan pada jam ke 5. Hal ini disebabkan kondisi cuaca yang mendung dan kemudian hujan 
yang berpengaruh pada perubahan suhu air hasil penyaringan masing-masing alat. Suhu pada proses tiap alat selalu berubah-ubah. Suhu tersebut dipengaruhi oleh udara di sekitar alat. Peningkatan suhu juga menyebabkan peningkatan metabolisme dan respirasi organisme air, dan selanjutnya mengakibatkan peningkatan konsumsi oksigen (Effendi, 2003).

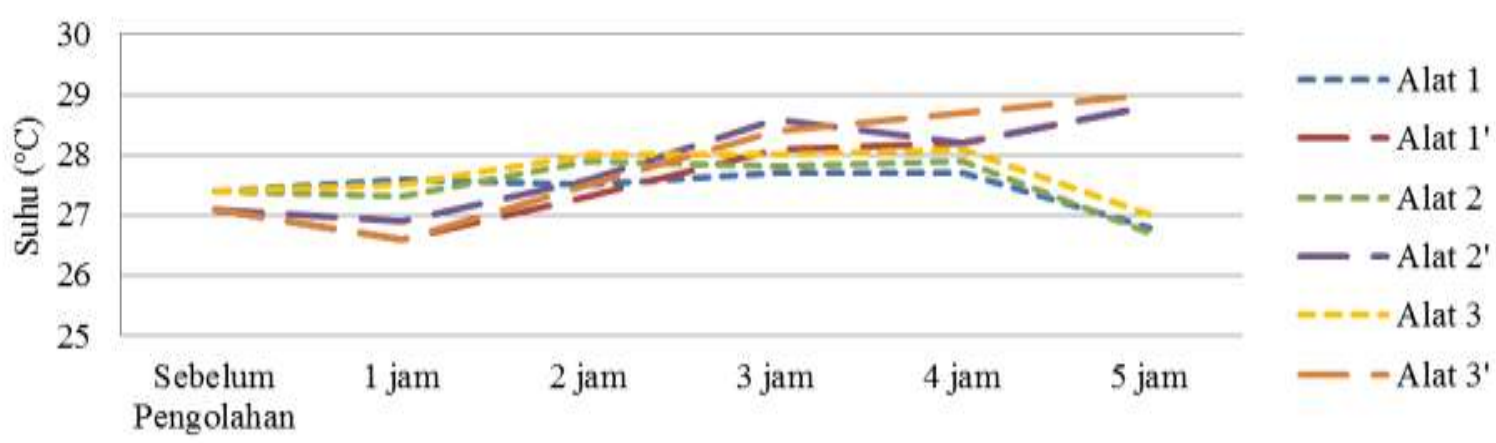

Gambar 3 Hasil uji suhu (alat 1, 2, dan 3 ialah percobaan pertama sedangkan alat 1', 2' dan 3' ialah percobaan kedua)

\section{Hasil Uji Oksigen Terlarut}

Pengukuran nilai oksigen terlarut sebelum pengolahan ialah $1,7 \mathrm{mg} / \mathrm{l}$ (pada percobaan pertama) dan $1,3 \mathrm{mg} / \mathrm{l}$ (pada percobaan kedua). Pada Tabel 3 dapat diketahui bahwa nilai oksigen terlarut sesudah pengolahan pada Alat 1, Alat 2 dan Alat 3. Sebagian besar oksigen dari dalam air berasal dari udara. Oleh karena itu kemampuan untuk mengisi oksigen kembali dengan cara kontak dengan udara merupakan hal yang sangat penting. Grafik hasil uji oksigen terlarut dapat dilihat pada Gambar 4.

Tabel 3 Oksigen terlarut sesudah pengolahan pada Alat 1, Alat 2 dan Alat 3

\begin{tabular}{|c|c|c|c|c|c|}
\hline \multicolumn{7}{|c|}{ Percobaan Pertama } \\
\hline \multirow{2}{*}{ Alat } & \multicolumn{7}{|c|}{ Pengukuran Oksigen Terlarut (mg/l) pada jam ke- } \\
\cline { 2 - 6 } & 1 & 2 & 3 & 4 & 5 \\
\hline 1 & 3,5 & 3,4 & 3,3 & 2,8 & 2,6 \\
\hline 2 & 3,6 & 3,5 & 3,2 & 2,8 & 2,3 \\
\hline 3 & 3,5 & 3,3 & 2,9 & 2,5 & 2,1 \\
\hline \multirow{7}{*}{ Alat } & 1 & \multicolumn{7}{|c|}{ Percobaan Kedua } \\
\hline & 4,2 & 3,2 & 2,6 & 2 & 5 \\
\hline & 4,6 & 3,4 & 2,2 & 2,5 & 1,6 \\
\hline 2 & 4,5 & 3,1 & 2,6 & 1,9 & 1,4 \\
\hline
\end{tabular}

Sumur Bor I pesantren Ar-Raudhatul Hasanah memiliki kedalaman \pm 200 meter. Kedalaman sumur bor tersebut berpengaruh pada rendahnya kandungan oksigen terlarut. Pada Gambar 4 dapat dilihat bahwa nilai oksigen terlarut mengalami peningkatan yang drastis pada satu jam pertama kemudian turun secara bertahap. Naiknya suhu air akan sebanding dengan penurunan nilai oksigen terlarut. Suhu air yang tinggi akan mengurangi jumlah oksigen terlarut dan dapat meningkatkan reaksi kimia di dalam air (Joko dan Rachmawati, 2016). Peningkatan oksigen terlarut yang tinggi pada satu jam pertama disebabkan oleh proses aerasi dan kontak air dengan zeolit. Diketahui bahwa zeolit mampu meningkatkan kadar oksigen terlarut dalam air, khususnya elemen $\mathrm{SiO}_{2}$ dan $\mathrm{Al}_{2} \mathrm{O}_{3}$. Pada tahap ini, peningkatan kadar oksigen terlarut secara tidak langsung terjadi akibat pengikatan amoniak yang bersifat mereduksi. Sejalan dengan penelitian Silaban (2012) mengatakan dalam hasil ujinya bahwa oksigen terlarut dari $6 \mathrm{mg} / \mathrm{l}$ yang ditambahkan zeolit $600 \mathrm{~g}$ dapat meningkatkan kadar oksigen terlarut hingga 6,4 mg/l kemudian turun secara bertahap sampai 6,2 mg/l. 


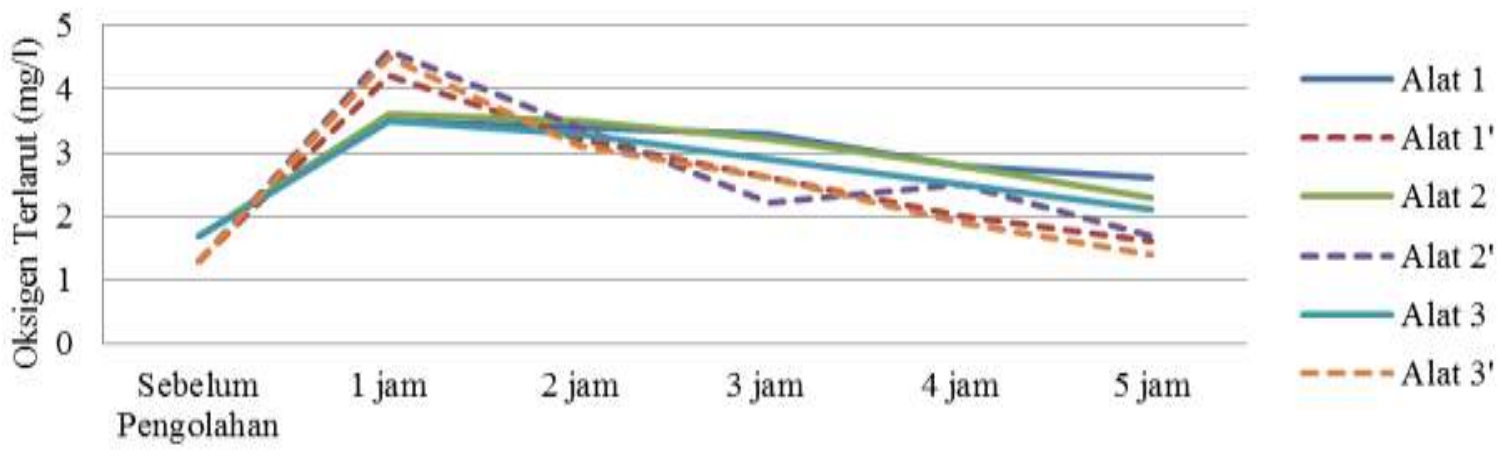

Gambar 4 Hasil uji oksigen terlarut (alat 1, 2, dan 3 ialah percobaan pertama sedangkan alat 1', 2' dan 3' ialah percobaan kedua)

\section{Hasil Uji Kadar Besi (Fe)}

Berdasarkan hasil penelitian yang telah dilakukan hasil uji kadar besi dapat dilihat pada Tabel 4. Pada percobaan pertama kadar Fe sesudah melewati alat penyaring air lebih konstan jika dibandingkan dengan percobaan kedua. Hal ini dapat disebabkan jarak pelaksanaan percobaan pertama dengan percobaan kedua yang terlalu lama membuat alat terpengaruh oleh faktor luar. Pada jam kedua saat percobaan kedua penurunan kadar
Fe membaik dikarenakan media telah tercuci kembali sejak alat dijalankan. Keefektifan masing-masing alat terlihat tidak terlalu berbeda dalam menurunkan kadar $\mathrm{Fe}$. Penurunan kadar $\mathrm{Fe}$ paling tinggi terdapat pada alat 1 yang berhasil menurunkan kadar Fe dari $0,72 \mathrm{mg} / \mathrm{l}$ menjadi $0,38 \mathrm{mg} / \mathrm{l}$ dengan efisiensi sebesar 47,22\%.

Tabel 4 Persentase penurunan kadar Fe sebelum dan sesudah melewati alat penyaring air

\begin{tabular}{|c|c|c|c|c|c|c|c|c|}
\hline \multirow[b]{3}{*}{ No. } & \multirow[b]{3}{*}{$\begin{array}{l}\text { Waktu } \\
\text { Sampling } \\
\text { (WIB) }\end{array}$} & \multirow[b]{3}{*}{$\begin{array}{c}\text { Alat } \\
\text { Penyaring } \\
\text { Air }\end{array}$} & \multicolumn{3}{|c|}{ Percobaan Pertama } & \multicolumn{3}{|c|}{ Percobaan Kedua } \\
\hline & & & \multicolumn{2}{|c|}{ Kadar Fe (mg/l) } & \multirow[b]{2}{*}{$\begin{array}{l}\text { Efisiensi } \\
\text { Penurunan } \\
\text { Kadar Fe } \\
\quad(\%)\end{array}$} & \multicolumn{2}{|c|}{ Kadar Fe (mg/l) } & \multirow[b]{2}{*}{$\begin{array}{l}\text { Efisiensi } \\
\text { Penurunan } \\
\text { Kadar Fe } \\
(\%)\end{array}$} \\
\hline & & & Sebelum & $\begin{array}{c}\text { Sesudah } \\
\text { (Setiap 1 } \\
\text { jam } \\
\text { dalam } 5 \\
\text { jam) }\end{array}$ & & Sebelum & $\begin{array}{l}\text { Sesudah } \\
\text { (Setiap 1 } \\
\text { jam } \\
\text { dalam } 5 \\
\text { jam) }\end{array}$ & \\
\hline \multirow{5}{*}{1} & 08.00 & \multirow{5}{*}{ Alat 1} & \multirow{15}{*}{0,72} & 0,4 & $44,44 \%$ & \multirow{15}{*}{0,5084} & 0,4511 & $11,27 \%$ \\
\hline & 09.00 & & & 0,41 & $43,06 \%$ & & 0,3914 & $23,01 \%$ \\
\hline & 10.00 & & & 0,38 & $47,22 \%$ & & 0,3973 & $21,86 \%$ \\
\hline & 11.00 & & & 0,41 & $43,06 \%$ & & 0,3899 & $23,31 \%$ \\
\hline & 12.00 & & & 0,42 & $41,67 \%$ & & 0,4235 & $16,70 \%$ \\
\hline \multirow{5}{*}{2} & 08.00 & \multirow{5}{*}{ Alat 2} & & 0,47 & $34,72 \%$ & & 0,4384 & $13,77 \%$ \\
\hline & 09.00 & & & 0,45 & $37,50 \%$ & & 0,337 & $33,71 \%$ \\
\hline & 10.00 & & & 0,45 & $37,50 \%$ & & 0,4208 & $17,23 \%$ \\
\hline & 11.00 & & & 0,45 & $37,50 \%$ & & 0,4139 & $18,60 \%$ \\
\hline & 12.00 & & & 0,44 & $38,89 \%$ & & 0,4373 & $13,99 \%$ \\
\hline \multirow{5}{*}{3} & 08.00 & \multirow{5}{*}{ Alat 3} & & 0,46 & $36,11 \%$ & & 0,4254 & $16,32 \%$ \\
\hline & 09.00 & & & 0,4 & $44,44 \%$ & & 0,3982 & $21,67 \%$ \\
\hline & 10.00 & & & 0,4 & $44,44 \%$ & & 0,352 & $30,77 \%$ \\
\hline & 11.00 & & & 0,4 & $44,44 \%$ & & 0,3343 & $34,25 \%$ \\
\hline & 12.00 & & & 0,4 & $44,44 \%$ & & 0,4063 & $20,09 \%$ \\
\hline
\end{tabular}

Grafik penurunan kadar $\mathrm{Fe}$ dapat dilihat pada Gambar 5. Penurunan Kadar Fe mengalami penurunan pada satu jam pertama dan berfluktuasi pada jam-jam berikutnya. 


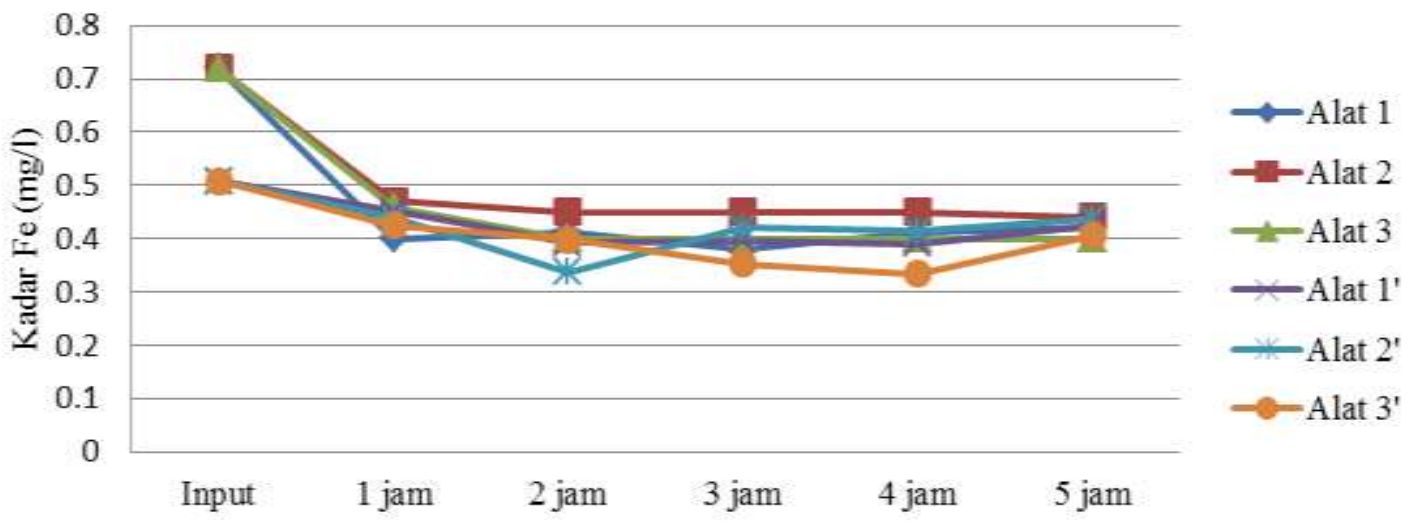

Gambar 5 Grafik penurunan kadar Fe

\section{Hasil Uji Kadar Mangan (Mn)}

Berdasarkan hasil penelitian yang telah dilakukan hasil uji kadar mangan dapat dilihat pada Tabel 5. Dari tabel tersebut dapat dilihat efisiensi penurunan Mn terbesar ialah $100 \%$ pada percobaan pertama dengan menggunakan semua alat dan 93,39\% pada percobaan kedua yang menggunakan alat 2 yaitu aerasi 2 tingkat dengan kombinasi zeolit dilanjutkan dengan saringan pasir, karbon aktif, dan zeolit. Penurunan kadar Mn baik dalam percobaan pertama maupun percobaan kedua dapat dikatakan baik dan efisien. Meskipun pada percobaan pertama terdapat lima hasil uji kadar Mn sesudah melewati alat penyaring yang belum berubah atau sama dengan kadar Mn sebelum penyaringan. Alat penyaring air lebih efisien dalam menurunkan kadar Mn bila dibandingkan dengan penurunan kadar $\mathrm{Fe}$. Grafik efisiensi penurunan kadar mangan (Mn) sesudah melewati alat penyaring air dapat di lihat pada Gambar 6.

Tabel 5 Persentase penurunan kadar Mn sebelum dan sesudah melewati alat penyaring air

\begin{tabular}{|c|c|c|c|c|c|c|c|c|}
\hline \multirow[b]{3}{*}{ No. } & \multirow[b]{3}{*}{$\begin{array}{l}\text { Waktu } \\
\text { Sampling } \\
\text { (WIB) }\end{array}$} & \multirow[b]{3}{*}{$\begin{array}{c}\text { Alat } \\
\text { Penyaring } \\
\text { Air }\end{array}$} & \multicolumn{3}{|c|}{ Percobaan Pertama } & \multicolumn{3}{|c|}{ Percobaan Kedua } \\
\hline & & & \multicolumn{2}{|c|}{ Kadar Mn (mg/l) } & \multirow[b]{2}{*}{$\begin{array}{c}\text { Penurunan } \\
\text { Kadar Mn } \\
\quad(\%)\end{array}$} & \multicolumn{2}{|c|}{ Kadar Mn (mg/l) } & \multirow[b]{2}{*}{$\begin{array}{c}\text { Penurunan } \\
\text { Kadar Mn (\%) }\end{array}$} \\
\hline & & & Sebelum & $\begin{array}{l}\text { Sesudah } \\
\text { (Setiap } 1 \\
\text { jam } \\
\text { dalam } 5 \\
\text { jam) }\end{array}$ & & Sebelum & $\begin{array}{l}\text { Sesudah } \\
\text { (Setiap } 1 \\
\text { jam } \\
\text { dalam } 5 \\
\text { jam) }\end{array}$ & \\
\hline \multirow{5}{*}{1} & 08.00 & \multirow{5}{*}{ Alat 1} & \multirow{15}{*}{0,10} & 0,10 & $0,00 \%$ & \multirow{15}{*}{0,0830} & 0,0519 & $37,49 \%$ \\
\hline & 09.00 & & & 0,00 & $100,00 \%$ & & 0,0184 & $77,88 \%$ \\
\hline & 10.00 & & & 0,00 & $100,00 \%$ & & 0,0245 & $70,44 \%$ \\
\hline & 11.00 & & & 0,00 & $100,00 \%$ & & 0,0302 & $63,57 \%$ \\
\hline & 12.00 & & & 0,00 & $100,00 \%$ & & 0,0212 & $74,48 \%$ \\
\hline \multirow{5}{*}{2} & 08.00 & \multirow{5}{*}{ Alat 2} & & 0,00 & $100,00 \%$ & & 0,0055 & $93,39 \%$ \\
\hline & 09.00 & & & 0,00 & $100,00 \%$ & & 0,0134 & $83,85 \%$ \\
\hline & 10.00 & & & 0,00 & $100,00 \%$ & & 0,0369 & $55,51 \%$ \\
\hline & 11.00 & & & 0,10 & $0,00 \%$ & & 0,0477 & $42,50 \%$ \\
\hline & 12.00 & & & 0,00 & $100,00 \%$ & & 0,0424 & $48,85 \%$ \\
\hline \multirow{5}{*}{3} & 08.00 & \multirow{5}{*}{ Alat 3} & & 0,10 & $0,00 \%$ & & 0,0240 & $71,13 \%$ \\
\hline & 09.00 & & & 0,00 & $100,00 \%$ & & 0,0300 & $63,89 \%$ \\
\hline & 10.00 & & & 0,10 & $0,00 \%$ & & 0,0406 & $51,10 \%$ \\
\hline & 11.00 & & & 0,10 & $0,00 \%$ & & 0,0460 & $44,54 \%$ \\
\hline & 12.00 & & & 0,00 & $100,00 \%$ & & 0,0556 & $32,96 \%$ \\
\hline
\end{tabular}




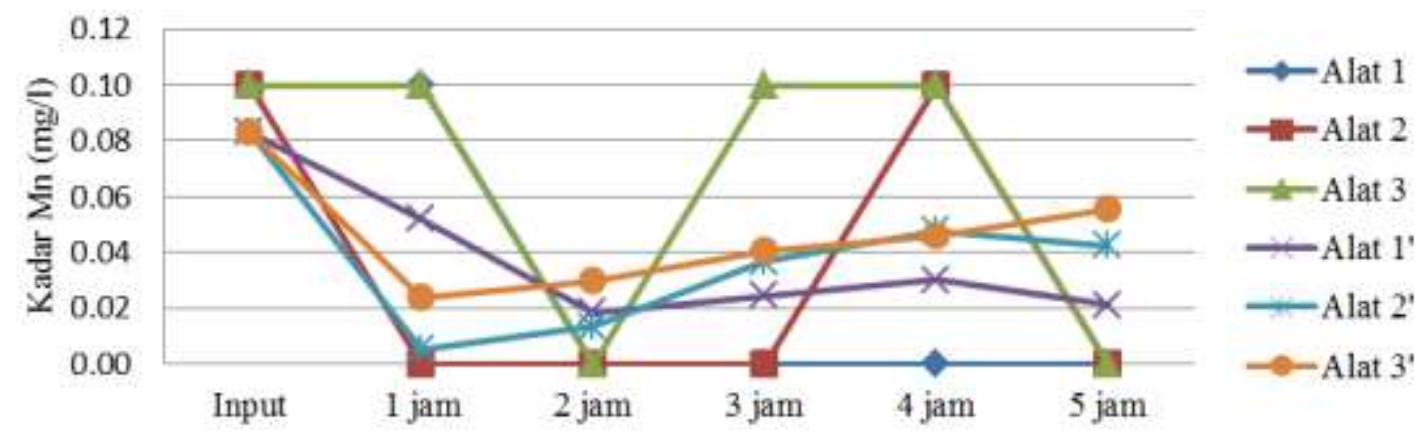

Gambar 6 Grafik penurunan kadar Mn Pembahasan Hasil Uji Kadar Besi (Fe) dan Mangan (Mn)

Kadar Fe sebelum penyaringan ialah 0,72 $\mathrm{mg} / \mathrm{l}$ (percobaan pertama) dan $0,5084 \mathrm{mg} / \mathrm{l}$ (percobaan kedua). Hasil ini menunjukkan bahwa kadar Besi $(\mathrm{Fe})$ tidak memenuhi baku mutu air minum $(0,3 \mathrm{mg} / \mathrm{l})$ bahkan baku mutu air bersih $(0,5 \mathrm{mg} / \mathrm{l})$ dalam Permenkes No.492/Menkes/Per/IV/2010. Sedangkan untuk kadar Mn sebelum penyaringan ialah $0,10 \mathrm{mg} / \mathrm{l}$ (percobaan pertama) dan 0,0830 $\mathrm{mg} / \mathrm{l}$ (percobaan kedua). Hasil tersebut sudah berada di bawah baku mutu air minum dalam Permenkes No.492/Menkes/Per/IV/2010 yaitu $0,4 \mathrm{mg} / \mathrm{l}$ namun tetap dapat dilihat penurunan kadar Mn pada tiap-tiap alat sesudah pengolahan. Dalam menurunkan kadar Fe dan Mn, zeolit lebih efektif dibandingkan dengan karbon aktif dan pasir. Sedangkan karbon aktif lebih efektif dibandingkan pasir. Hal ini menjadi pertimbangan peneliti dalam meletakkan susunan media dari bawah ke atas yaitu pasir, karbon aktif, dan zeolit. Sejalan dengan penelitian Handarbeni (2013) yang mengatakan keefektifan susunan media filter pasir silika-zeolit-arang aktif sebesar 91,83 $\%$, zeolit-arang aktif-pasir silika sebesar 93,56\% dan arang aktif-pasir silika-zeolit sebesar $92,29 \%$.

Dari penelitian yang telah dilaksanakan ternyata alat 1 , alat 2 , dan alat 3 mampu menurunkan kadar Fe dan Mn pada air sumur bor I Pesantren Ar-Raudhatul Hasanah meskipun penurunan kadar $\mathrm{Fe}$ dan Mn masih belum maksimal dan belum memenuhi baku mutu air minum. Penurunan kadar Fe dan Mn yang belum maksimal ini dapat disebabkan, oleh (1) rentang ukuran partikel zeolit yang terlalu besar yaitu $\leq 10$ $\mathrm{mm}$ memungkinkan adanya perbedaan jumlah zeolit dan ukurannya pada tiap alat, (2) luas permukaan zeolit yang kecil dikarenakan ukuran zeolit yang masih besar sehingga daya adsorpsi zeolit rendah, (3) ketebalan tiap-tiap media yang belum memadai (4) pasir dan zeolit yang tidak diaktivasi terlebih dahulu.

Keefektifan penuranan kadar $\mathrm{Fe}$ dan $\mathrm{Mn}$ lebih teruji dengan menggunakan zeolit yang sudah diaktivasi terlebih dahulu. Seperti pada penelitian Karnaningroem dan Hardini (2011) yang melakukan uji filter dengan menggunakan media mangan zeolit dan karbon aktif. Mangan zeolit ialah zeolit yang sudah diaktivasi terlebih dahulu. Diamater media karbon aktif ialah $1 \mathrm{~mm}$ dan mangan zeolit ialah $2 \mathrm{~mm}$. Perbandingan media ialah 1:1 dengan ketebalan $40 \mathrm{~cm}$ dapat menurunkan kadar Fe dari $1 \mathrm{mg} / \mathrm{l}$ menjadi $0,024 \mathrm{mg} / \mathrm{l}$ atau dengan efisensi penyisihan sebesar 90,31\% dan kadar Mn dari $1 \mathrm{mg} / \mathrm{l}$ menjadi $0,016 \mathrm{mg} / \mathrm{l}$ atau dengan efisensi penyisihan sebesar 97,62\%.

Kemampuan zeolit sebagai adsorben untuk menghilangkan mangan dari dalam air lebih besar dibandingkan dengan karbon aktif (Rahmawati, 2009). Daya serap karbon aktif dipengaruhi oleh sifat serapan, suhu, $\mathrm{pH}$, dan waktu kontak (Sembiring dan Tuti, 2003). Hardini dan Hardini dan Karnaningroem (2011) menyatakan dalam penelitiannya bahwa semakin tebal media karbon aktif dan zeolit maka efisiensi penyisihan semakin tinggi. Semakin lama waktu kontak maka semakin banyak kesempatan partikel karbon aktif untuk bersinggungan dengan logam besi yang terikat di dalam pori-pori karbon aktif (Asbahani, 2013).

Hal tersebut sejalan dengan penelitian Panigoro (2015) yang telah menganalisis kadar Fe dan Mn pada air sumur setelah dilakukan proses penyaringan berdasarkan ketebalan pasir $40 \mathrm{~cm}$ dan karbon aktif 20 
$\mathrm{cm}$ dengan efektifitas penyisihan kadar $\mathrm{Fe}$ sebesar 91,87 \% dan kadar Mn sebesar 96,21 $\%$. Sementara itu, pada ketebalan pasir 80 $\mathrm{cm}$ dan karbon aktif $40 \mathrm{~cm}$ dengan efektifitas penyisihan kadar Fe sebesar 98,12 $\%$ dan Mn sebesar 97,09\%.

Semakin besar ketebalan pasir dan karbon aktif yang digunakan, maka semakin tinggi juga penurunan kadar $\mathrm{Fe}$ dan $\mathrm{Mn}$ yang terjadi selama air mengalir melewati poripori media penyaring. Tetapi penurunannya tidak beraturan atau tidak sama setiap sampelnya bisa saja dipengaruhi oleh faktor luar (Panigoro dkk, 2015). Adapun beberapa faktor yang mempengaruhi efektivitas saringan pasir antara lain (Kusnoputranto, 1994): jenis pasir, diameter pasir, ketebalan pasir, lama penahanan media, dan penambahan oksidator $\mathrm{KMnO} 4$ (pengaktifan pasir). Kelarutan $\mathrm{Fe}$ dalam air dipengaruhi oleh (Munthe, 2013): kedalaman, pH, Suhu, bakteri besi, dan $\mathrm{CO}_{2}$ agresif.

Jarak kran input setiap alat dengan wadah aerasi maupun wadah media ialah $20 \mathrm{~cm}$, jarak tersebut juga sama dengan jarak antar wadah aerasi dan jarak wadah aerasi dengan wadah media yaitu $20 \mathrm{~cm}$. Setiap jarak tersebut mempunyai waktu kontak aerasi selama 0,2 detik. Pada alat 1 dan alat 2 waktu kontak aerasi berlangsung lebih lama yaitu $3 \times 0,2$ detik $=0,6$ detik, sedangkan pada alat 3 hanya berlangsung selama 0,2 detik. Waktu kontak yang terlalu singkat ini memungkinkan $\mathrm{Fe}$ dan $\mathrm{Mn}$ masih dalam kondisi larut dalam air. Baik hidroksida besi (valensi 2) maupun hidroksida mangan (valensi 2) masih mempunyai kelarutan yang cukup besar (Asmadi dkk, 2011). Semakin bertambahnya waktu injeksi udara ke dalam air baku akan semakin memaksimalkan terjadinya kontak air dengan udara sehingga oksigen terlarut akan semakin banyak (Joko dan Rachmawati, 2016). Asmadi dkk (2011) mengatakan untuk mengoksidasi setiap 1 $\mathrm{mg} / \mathrm{l}$ kadar besi $(\mathrm{Fe})$ dibutuhkan $0,14 \mathrm{mg} / \mathrm{l}$ oksigen dan setiap $1 \mathrm{mg} / \mathrm{l}$ mangan (Mn) dibutuhkan $0,29 \mathrm{mg} / 1$.

Pembuatan wadah aerasi dengan jarak antar wadah $20 \mathrm{~cm}$ dan dengan menggunakan atau tanpa zeolit ialah berlandaskan penelitian terdahulu. Sari dan Karnaningroem telah melakukan penelitian yang membandingkan efisiensi casscade aerator dengan menggunakan mangan zeolit dan tanpa mangan zeolit dalam menurunkan kadar $\mathrm{Fe}$ dan $\mathrm{Mn}$. Efisiensi penurunan $\mathrm{Fe}$ dan $\mathrm{Mn}$ yang paling optimal terjadi pada perlakuan dengan menggunakan mangan zeolit, dengan nilai sebesar 39,4\% dan 40,1\%, sedangkan yang tanpa mangan zeolit sebesar 36,2\% dan $39 \%$. Penelitian Rachmawati (2016) yang menggunakan tray aerator 6 step dengan jarak antar nampan $25 \mathrm{~cm}$ dengan penambahan zeolit dan karbon aktif untuk menurunkan kadar $\mathrm{Fe}$ air sumur gali. Aerasi dengan penambahan media kontak zeolit memiliki rata-rata efisiensi sebesar 93,93\%. Aerasi dengan penambahan media kontak karbon aktif memiliki rata-rata efisiensi sebesar $91,70 \%$. Dalam proses aerasi terdapat beberapa faktor yang mempengaruhi perpindahan oksigen, di antaranya sebagai berikut (Bennefield, 1980): suhu, kejenuhan oksigen, karateristik air, dan turbulensi air.

\section{Hasil Uji Debit}

Debit input pada tiap alat disamakan pada $240 \mathrm{ml} /$ menit. Pemilihan debit $240 \mathrm{ml} / \mathrm{menit}$ disesuaikan dengan kemampuan maksimum setiap alat untuk menampung air agar tidak ada air yang keluar dari alat. Berdasarkan hasil pengukuran debit yang telah dilakukan terhadap output pada alat 1 , alat 2 , dan alat 3 setiap 1 jam sekali dalam 5 jam didapatkan hasil yang sama pada debit input yaitu 240 $\mathrm{ml} /$ menit. Debit yang stabil tersebut menunjukkan media pasir, karbon aktif dan zeolit yang digunakan belum mengalami kejenuhan setelah digunakan selama 10 jam. Hal ini sejalan dengan penelitian Yulianti dkk (2016) yang telah melakukan penelitian untuk mengetahui umur pemakaian zeolit dan karbon aktif. Dari penelitian tersebut diketahui bahwa batas umur pemakaian zeolit alam dan karbon aktif maksimal dalam alat pengolah air sumur sistem adsorpsi adalah sebulan. Jika media sudah jenuh dapat dilakukan pencucian dengan sitem backwash.

\section{Analisa Statistik}

\section{Analisa Statistik untuk Kadar Besi (Fe)}

Uji Kruskall-Wallis digunakan untuk mengetahui ada tidaknya perbedaan penurunan $\mathrm{Fe}$ pada alat penyaring air. Berdasarkan data hasil penelitian kadar besi 
(Fe) yang selanjutnya dianalisis secara statistik, menunjukkan bahwa nilai $\mathrm{x}=$ 0,028 . Karena $\mathrm{p}(0.028)<0.05$, artinya Ho ditolak. Sehingga menunjukkan bahwa ada perbedaan kadar Fe pada alat 1, alat 2 dan alat 3 .

Uji Post Hoc merupakan salah satu teknik uji statistik yang digunakan untuk melihat perbandingan rata-rata pasangan alat yang berbeda secara signifikan. Hasil Uji Post Hoc menunjukkan bahwa rerata kadar $\mathrm{Fe}$ pada perbandingan alat 1 dengan alat 2 nilai $\mathrm{p}(0.103)>0.05$ artinya Ho diterima sehingga menyimpulkan tidak ada perbedaan kadar Fe. Perbandingan alat 1 dengan alat 3 nilai $\mathrm{p}(0.532)>0.05$ artinya Ho diterima sehingga menyimpulkan tidak ada perbedaan kadar Fe. Perbandingan alat 2 dengan alat 3 nilai $\mathrm{p}(0.028)<0.05$ artinya Ho ditolak sehingga menyimpulkan ada perbedaan kadar Fe.

Uji Wilcoxon digunakan untuk menganalisis hasil uji dari masing-masing alat terhadap kadar $\mathrm{Fe}$ sebelum dan sesudah dilakukan penyaringan. Hasil Uji Wilcoxon pada alat 1 menunjukkan bahwa nilai $\mathrm{x}=0,005$. Karena $\mathrm{p}(0.005)<0.05$, artinya Ho ditolak. Sehingga menunjukkan bahwa ada perbedaan kadar Fe sebelum dan sesudah melewati alat 1 . Pada alat 2 menunjukkan bahwa nilai $\mathrm{x}=0,005$. Karena $\mathrm{p}(0.005)<$ 0.05 , artinya Ho ditolak. Sehingga menunjukkan bahwa ada perbedaan kadar $\mathrm{Fe}$ sebelum dan sesudah melewati alat 2. Pada alat 3 menunjukkan bahwa nilai $\mathrm{x}=0,005$. Karena p $(0.005)<0.05$, artinya Ho ditolak. Sehingga menunjukkan bahwa ada perbedaan kadar Fe sebelum dan sesudah melewati alat 3 .

\section{Analisa Statistik untuk Kadar Mangan (Mn)}

Uji Kruskall-Wallis digunakan untuk mengetahui ada tidaknya perbedaan penurunan $\mathrm{Mn}$ pada alat penyaring air. Berdasarkan data hasil penelitian kadar besi (Fe) yang selanjutnya dianalisis secara statistik, menunjukkan bahwa nilai $\mathrm{x}=$ 0,146 . Karena p $(0.146)>0.05$, artinya Ho diterima. Sehingga menunjukkan bahwa tidak ada perbedaan kadar Mn pada alat 1, alat 2 dan alat 3 .
Uji Wilcoxon digunakan untuk menganalisis hasil uji dari masing-masing alat terhadap kadar Mn sebelum dan sesudah dilakukan penyaringan. Hasil Uji Wilcoxon pada alat 1 menunjukkan bahwa nilai $\mathrm{x}=0,007$. Karena $\mathrm{p}(0.007)<0.05$, artinya Ho ditolak. Sehingga menunjukkan bahwa ada perbedaan kadar Mn sebelum dan sesudah melewati alat 1 . Pada alat 2 menunjukkan bahwa nilai $x=0,007$. Karena $\mathrm{p}(0.007)<$ 0.05, artinya Ho ditolak. Sehingga menunjukkan bahwa ada perbedaan kadar Mn sebelum dan sesudah melewati alat 2 . Pada alat 3 menunjukkan bahwa nilai $\mathrm{x}=$ 0,018. Karena p $(0.018)<0.05$, artinya Ho ditolak. Sehingga menunjukkan bahwa ada perbedaan kadar Mn sebelum dan sesudah melewati alat 3 .

\section{SIMPULAN}

Penurunan kadar $\mathrm{Fe}$ yang paling baik ialah menggunakan alat 1 yaitu aerasi 2 tingkat dilanjutkan dengan saringan pasir, karbon aktif, dan zeolit dengan efisiensi penurunan sebesar 47,22 \%. Sedangkan efisiensi penurunan kadar $\mathrm{Mn}$ yang terdapat pada setiap alat sebesar $100,00 \%$.

Tidak ada perbedaan yang nyata antara alat 1 dengan alat 3 dalam menurunkan kadar $\mathrm{Fe}$ $(\mathrm{p}=0,532)$. Ada perbedaan yang nyata antara alat 2 dengan alat 3 dalam menurunkan kadar Fe $(\mathrm{p}=0,028)$.

Tidak ada perbedaan yang nyata antara alat 1 dengan alat 3 dalam menurunkan kadar Mn $(\mathrm{p}=0,135)$. Tidak ada perbedaan yang nyata antara alat 2 dengan alat 3 dalam menurunkan kadar $\mathrm{Mn}(\mathrm{p}=0,769)$.

Ada perbedaan penurunan kadar Fe dan Mn sebelum dan sesudah melewati alat 1 , alat 2 dan alat 3.

Debit input dan output pada tiap-tiap alat ialah $240 \mathrm{ml} / \mathrm{menit}$. Tidak ada penurunan debit setelah dilakukan penelitian selama 10 jam (5 jam pada percobaan pertama dan 5 jam pada percobaan kedua).

\section{DAFTAR PUSTAKA}

Asbahani, 2013. Pemanfaatan Limbah Ampas Tebu Sebagai Karbon Aktif untuk Menurunkan Kadar Besi pada Air Sumur. Jurnal. Universitas Tanjungpura. Pontianak 
Asmadi., Khayan., dan Kasjono, H. S. 2011. Teknologi Pengolahan Air Minum. Gosyen: Yogyakarta.

Bennefield, L.D., Randall, C.W. 1980. Biological Process Design for Wastewater Treatment. PrenticeHall, Inc.

Effendi, 2003. Telaah Kualitas Air. Kanisius: Yogyakarta

Fatriani. 2009. Pengaruh Konsentrasi dan Lama Perendaman Arang Aktif Tempurung Kelapa Terhadap Kadar $\mathrm{Fe}$ dan pH Air Gambut. Laporan Hasil Penelitian. Unlam. Banjarbaru.

Handarbendi, L. S. 2013. Keefektifan Variasi susunan Media Filter Arang Aktif, Pasir dan Zeolit dalam Menurunkan Kadar Besi (Fe) Air Sumur. Tugas Akhir. UMS. Surakarta.

Hardini, I., dan Karnaningroem, N. 2011. Peningkatan Kualitas Air Sumur Gali Menjadi Air Bersih Menggunakan Filter Mangan Zeolit dan Karbon Aktif: Studi Kasus Air Sumur Gali Pemukiman Desa Banjar PO Sidoarjo. Jurnal. ITS. Surabaya.

Jamilatun, S., dan Setyawan, M. 2014. Pembuatan Arang Aktif dari Tempurung Kelapa dan Aplikasinya untuk Penjernihan Asap Cair. Jurnal. UAD. Yogyakarta.

Joko, T., dan Rachmawati, S. 2016. Variasi Penambahan Media Adsorpsi Kontak Aerasi Sistem Nampan Bersusun (Tray Aerator) Terhadap Kadar Besi (Fe) Air Tanah Dangkal di Kabupaten Rembang. Jurnal. Undip. Semarang.

Kusnaedi. 2010. Mengolah Air Kotor untuk Air Minum. Penebar Swadaya: Jakarta.

Kusnoputranto, $1994 . \quad$ Kesehatan Lingkungan. FKM UI: Jakarta.

Linsley, R. K. 1985. Teknik Sumberdaya Air (Terjemahan Djoko Sasongko).Penerbit Airlangga: Jakarta.

Munthe, A. 2013. Pengolahan Air Bersih Dengan Kombinasi Jarak Jatuh Pada Aerasi Bertingkat dan Diameter Pasir Pada Saringan Pasir Dalam Menurunkan Kadar Fe dan Mn Pada Air Sumur Gali Di
Desa Pelawi Selatan Kabupaten Langkat Tahun 2013. Tesis. USU. Medan.

Panigoro, S. A. N., Saraswati, D., Prasetya, E. 2015. Pengaruh Variasi Ketebalan Pasir Dan Karbon Aktif Pada Media Saringan Pasir Lambat Terhadap Penurunan Kadar Besi (Fe) Dan Mangan (Mn) Pada Air Sumur (Suatu Penelitian di Kelurahan Pulubala Kecamatan Kota Tengah Kota Gorontalo).

Peraturan Menteri Kesehatan Republik Indonesia Nomor 492/Menkes/Per/IV/2010 Tentang Persyaratan Kualitas Air Minum.

Rachmawati, S., Joko, T., dan Astorina, N. 2016. Perbedaan Variasi Penambahan Media Adsorpsi Kontak Aerasi Sistem Nampan Bersusun (Tray Aerator) Terhadap Kadar Besi (Fe) Air Sumur Gali Di Desa Jatihadi Kecamatan Sumber Kabupaten Rembang. Jurnal. Undip. Semarang.

Rahayu, A., Masturi, dan Yulianti, I. Pengaruh Perubahan Massa Zeolit Terhadap Kadar pH Limbah Pabrik Gula Melalui Media Filtrasi. Jurnal. UNS. Semarang.

Rahmawati, A. 2009. Efisiensi Filter PasirZeolit dan Filter Pasir- Arang Tempurung Kelapa dalam Rangkaian Unit Pengolahan Air Untuk Mengurangi Kandungan Mangan Dari Dalam Air. Seminar Internasional Hasil- Hasil Penelitian, Eksakta 3. Universitas Sebelas Maret. Surakarta.

Sari, W. K., dan Karnaningroem, N. Studi Penurunan Besi (Fe) Dan Mangan (Mn) Dengan Menggunakan Casscade Aerator Dan Rapid Sand Filter Pada Air Sumur Gali. Jurnal. ITS. Yogyakarta.

Sembiring, M dan Tuti, S. 2003. Arang Aktif ( Pengenalan dan Proses Pembuatannya). USU. Medan.

Silaban, T. F., Santoso, L., dan Suparmono. 2012. Dalam Peningkatan Kinerja Filter Air Untuk Menurunkan Konsentrasi Amonia Pada Pemeliharaan Ikan Mas (Cyprinus carpio). Jurnal. Unlam. Lampung. 
Soemirat, J. 2014. Kesehatan Lingkungan. Gajah Mada University Press: Yogyakarta.

Suprihatin, dan Suparno, O. 2013. Teknologi Proses Pengolahan Air Untuk Mahasiswa Dan Praktisi Industri. IPB Press. Bogor.
Yulianti, D. M., Aminatum, T., dan Yuliati. 2016. Pengaruh Umur Pemakaian Zeolit Alam dan Arang Dalam Penyaringan Air Sumur Sistem Adsorpsi Terhadap Kualitas Bakteriologis Air. Jurnal. UNY. Yogyakarta. 